\title{
SEMANTIC ANALYSIS OF THETA ROLES OF VERBS IN THE MAH MERI LANGUAGE
}

\author{
Maisarah \\ University of Malaya, Kuala Lumpur, Malaysia \\ Email: myra.rais@gmail.com \\ Kais Amir Kadhim \\ University of Malaya, Kuala Lumpur, Malaysia \\ Email: kaisamir@um.edu.my \\ Zahid Ali Veesar \\ Department of English, Lasbela University, Uthal, Pakistan \\ Email: zahiimahii85@gmail.com
}
APA Citation: Maisarah, Kadhim, K. A., \& Veesar, Z. A. (2016). Semantic analysis of Theta Roles of verbs in the Mah Meri language. English Review: Journal of English Education, 5(1), 49-70

\begin{abstract}
The Mah Meri language, one of the severely endangered languages of Malaysia, is facing the threat of extinction. In order to save valuable information of this language, this paper focuses on one of its aspects, the Theta Roles in relation to the verbs. Using Radford's (1997 \& 2009) theory of Theta Roles, this study analyzes and explores the verb phrase of Mah Meri. The main objective of this study is to establish the Theta Roles in relation to verbs in the Mah Meri language. In order to fully understand the verb structures, the morphological entities of affixes such as prefixes and suffixes are studied. Moreover, the word order of the sentential constructions are also analyzed according to active and passive forms. These are done in tandem with analyzing the pronouns in relation to the placement of verbs in a Mah Meri sentential construction. It is found that Theta Roles are present in the data except for the Theta Role Recipient. However, this is not due to the lack of the Theta Role of Recipient in the Mah Meri language; rather it is due to the limitation of the scope in this study as data is analyzed based on the interviews only. On the other hand, the Theta Role of Agent is clearly evident in the Mah Meri language.

Keywords: Mah Meri Language, Argument Structure, Theta Roles, Thematic Relations
\end{abstract}

\section{INTRODUCTION}

It is unfortunate to note that the linguistic studies on the Mah Meri language are limited in number, if not practically scarce. In general, there are a few Mah Meri linguistic studies available in the area of phonology and phonetics, and also on its grammar. However, to the researcher's knowledge, only one study has focused specifically on the syntax of the language. Following
Blagden's study, the language of Mah Meri was analyzed to be an Austroasiatic Mon-Khmer language in previous times. This view was supported by Omar (2006) and Sebeok (1942). Sebeok (1942) discussed the Mon-Khmeric origins of the Sakai language. He mentioned of Blagden's arrival at this conjecture by presenting morphological, lexical arguments, and numerical systems analysis. Nevertheless, in recent times, 
Mah Meri is said to have adopted the Austronesian features of the Malay language (Omar, 2006). One of the most notable studies on Mah Meris was headed by Omar and her team from the University of Malaya, resulting to the publication of a book entitled 'Bahasa Mah Meri' which was published in 2006. This book is a valuable asset as it presents the basic grammatical structures and vocabulary of the Mah Meri language. In this research, several aspects were highlighted: Ethnography of the Mah Meri people in Kampung Bukit Bangkong, Phonetics and Phonology, Phonemes, Morphology, Verb Phrase, Adjectival Phrase, and Syntax. However, each of these categories was not explored in detail as its main aim was to provide a general account.

Yok (2006) had given a traditional account of syntactic structures of Mah Meri. Such accounts of the syntactic structures of its sentences are divided into Declarative Sentences, Sentences with a Null-Subject, Theme-Rheme, Negative Sentences, Passives, Interrogatives as well as Imperatives. Besides, Peh and Arshad (1981) have also described the syntactic structures of the Mah Meri people in Kampung Sungai Bumbun in Carey Island. In Yok's study, the syntax of Mah Meri concentrated on the aspects of traditional grammar. The participants in Yok's study were from Kampung Sungai Bumbun. In terms of participants, both studies were conducted on the native speakers who were above 40 years old. Besides, Kruspe (2004) has also studied phonetics and phonology of Mah Meri language. She also studied phonetics of the Mah Meri language with Hajek. Kruspe and Hajek (2009) indicated that the Mah Meri language was without a written tradition. Thus, this research contributes to the dearth of literature on the phonetic forms or written representations of the Mah Meri language. In another work closely related to the Mah Meri language about the registers in Mah Meri (Stevens, Kruspe, \& Hajek, 2006), it is found that Mah Meri shows a two-way register system. As a preliminary finding, the researchers found that Mah Meri language's registers to be akin to the complexity of other Mon- Khmer languages. Another contribution of Kruspe was publication of a dictionary of Mah Meri in 2010. She collected the data from the Mah Meri community in Bukit Bangkong. Similarly, Omar (2006) also compiled a dictionary of the Mah Meri language. The words in this dictionary are translated into both Malay and English.

Although generative grammarians indicate that the terms of Theta Role and Thematic Relations are interchangeably used. Carnie makes a distinction between the two terms (as cited in Veesar, Sriniwass, \& Kadhim, 2015a). Carnie (2007) defines Theta Roles as 'a bundle of thematic relations associated with a particular argument'. In contrast, the term 'Thematic Relations' is referred to as the semantic relation between an argument and a predicate (Veesar, Kadhim, \& Sriniwass, 2015b). Thus, there may be more than one possible Thematic Relations for an argument with a predicate (Veesar, Kadhim, Shah, \& Khuhro, 2016a). Nevertheless, according to ThetaCriterion Theory, each argument is assigned one and only one theta role and each theta role is assigned to one and only one argument (Chomsky, 1988). Hence, an argument may have many possible Thematic Relations but assumes only one type of Theta Role. It is seen that although there are five thematic relations linked to the argument of 
Theme; for example, the definite Theta Roles are only three in relation to the predicate. Hence, each argument only assumes one prominent and syntactically dominant Theta Role (Veesar, Kadhim, \& Bagudu, 2016b). An argument having more than one Theta Roles is considered ungrammatical in the opinion of Carnie (2007). Hence, this is a marked difference from the understanding of Carnie compared to Radford (1997).

Nevertheless, even though Carnie pointed out that though he might not necessarily agree with the terms of Theta Role and Thematic Relations to be used interchangeably, he did not object to the practice entirely. This is due to the norm of interchangeably using the Theta Role and Thematic Relations terminologies. However, both Radford (1997; 2009) and Carnie (2007) agree on the basis of analyzing Theta Roles. To illustrate, both of them stress that in order to analyze Theta Roles, utmost importance must be given to predicates and arguments. Both elaborate that recognition of predicates and arguments are essential to identify the argument's Theta Role. In Luraghi and Parodi (2008), the term Theta Role is expressed through the symbol - role. In their book, they mentioned that the term Theta Roles refers to the semantic roles. Furthermore, they express that in Transformational Generative Grammar (TGG), the relations of semantics between verbs and their arguments are already designated in terms of Theta Roles. To further elaborate this point, a Theta Role is a semantic role which has a Noun Phrase or Determiner Phrase by default. These NPs or DPs might assume the role of Agent, Patient, Theme, Experiencer and Beneficiary. It is further elaborated that the argument assumes their specific Theta Role during the process of Merge.

\section{METHOD}

Mah Meri, also known as Besisi and Betise', is an aboriginal Mon-Khmer language spoken in Malaysia. It is the only such language spoken on the coast in Malacca outside of the capital Kuala Lumpur. The small number of speakers is increasing. The number of speakers in 2003 was 3,000 speakers. With regard to data collection, Tok Batin Salleh, the Head of Kampung Sungai Rambai was the only participant for this particular study. The data were collected from interviews with Tok Batin Salleh in the Mah Meri language. In particular, the researcher's focus was to ask questions in relation to the participant's daily activities such as food, entertainment, culture, and so forth. The participant was interviewed on two occasions in November 2012.

The first interview was conducted a week after an engagement ceremony. To elaborate, firstly, the interviewer obtained verbal consent for the requirement of the research from the participant. To do so, the interviewer stated the purpose and objectives of the research to the participant. The participant was selected based on his age, health condition of oral organs of speech and also the fluency of the language. In addition to this, the researcher included an additional criterion which was fluency of both the target language of Mah Meri and the language of interview which was standard Malay. The researcher also required the participant to be fluent in both Mah Meri and standard Malay language due to the researcher's inability to speak Mah Meri fluently. Besides, the participant was also asked his permission to record the interviews using an mp3 player for the purpose of documentation. After the consent was obtained, the researcher proceeded to 
conduct the interview based on the familiar themes in the participant's life.

The next step in order to elicit the data is to understand the terminologies of the Theta Roles according to Radford (1997). Hence, in referring to his understanding of Theta Roles, the researcher determines the arguments with predicates accordingly. His understanding theory of Theta Roles is summarised below.

Table 1. Radford's understandings of Theta Roles

\begin{tabular}{lll}
\hline Role & Gloss & Example \\
\hline THEME & Entity undergoing the effect of some action & Mary fell over \\
AGENT & Entity instigating some action & Debbie killed Henry \\
EXPERIENCER & Entity experiencing some psychological state & I like syntax \\
LOCATIVE & Place in which something is situated or takes place & He hid it under the bed \\
GOAL & Entity representing the destination of some other entity & John went home \\
SOURCE & Entity form which something moves & He returned from Paris \\
INSTRUMENT & Means used to perform some action & He hit it with a hammer \\
& &
\end{tabular}

Theta-role ( $\theta$-role) is a bundle of thematic relations associated with a particular argument. While in ThetaCriterion, each argument is assigned one and only one theta-role. Each theta-role is assigned to one and only one argument. Therefore, relating to the table above, the sentential constructions in the data pay close attention to the arguments.

Arguments, which are also known as noun phrase (NPs), are identified in the Mah Meri language. Once the argument is identified, the predicate related to the arguments are analysed. For example, if the researcher examines the sentential construction, e ed suka nasi pulut wajik, it is clear that there are two arguments in this particular sentential construction. The argument $e$ ed assumes the role of Experiencer while the argument nasi pulut wajik undertakes the role of Theme.

In relation to the second objective of the study, the analysis focuses on the three main verb types of language, namely Transitive, Ditransitive and Intransitive. This is also following Radford's explanation of transitivity and valency. Hence, all the sentential constructions with arguments and predicates are analysed according to their semantic relation to one another. This research also addresses the verb structures of Mah Meri having Theta Roles by examining their transitivity and valency. Other aspects like pronouns are taken into account accordingly.

\section{RESULTS AND DISCUSSION}

Theta Roles play a pertinent role in deducing the initial level of understanding a Mah Meri sentential construction. The semantic understanding of the constituents can determine whether a sentential construction is syntactically correct. The sentential constructions in the data pay close attention to the arguments. Arguments are identified in the Mah Meri Language. Once the argument is identified, the predicate related to the arguments is analyzed. Therefore, all the sentential constructions with arguments and predicates are analysed according to their semantic relation to one another. This paper also addresses the verb structures of the Mah Meri language that having Theta Roles through their transitivity and valency. Hence, the Theta Roles are addressed in the following order: Agent, Theme, Experiencer, Benefactor, Instrument and Locative. 


\section{Agent}

All sentences which bear the Agent Theta Role are featured. However, only ten verbs are demonstrated here in this section to avoid redundant information in the analysis. The related verbs which are linked to this section include: Kabe/Beh, Masak and Hagak.

\section{a. Agent Theta Role in Relation to the Verb Kabe/Beh}

1) eed beh nasi pulut wajik sendiri (MahMeri)

saya buat nasi pulut wajik sendiri (Malay)

I make rice pulut wajik myself (English)

I make pulut wajik rice by myself.

2) kedo eed yang beh wajik untuk eed

isteri saya yang buat wajik untuk saya

Wife I that make wajik for me

My wife makes wajik for me.

3) ngki golbeh nake

dia ambil buat itu

he take make that

He takes (and) makes that.

4) ngki macam-macam kejak kabe

dia macam-macam kerja buat

he various work do

He (has) done various types of work.

From the data in above, it is clear that the verb beh is a contraction of the verb kabe; thus, they have the same semantic denotation. In the examples 1 and 2, the predicate/verb beh is linked to the Agent theta role. To reiterate, an Agent is identified as someone who initiates an action and could be capable of volition. In the sentential construction of 1 , the noun e ed is deciphered as the Agent who is initiating the action of making pulut wajik rice. In contrast, the sentential construction of 2 shows the noun kedo $e$ ed as an Agent. Similar to sentence 1, sentence 2 has also an Agent who is capable to make pulut wajik rice and acts out on her own volition. However, in the sentential construction of 3 , it is established that the Agent is the noun $n g k i$. Ngki is described as an Agent that is capable of volition and able to initiate the action. The same pattern emerges with the noun constituent $n g k i$ in the sentence of 4 . Similarly, ngki in this sentential construction is also the initiator and acts with volition.

\section{b. Agent Theta Role in Relation to the Verb Masak}

5) bila eed hagak suroh gendei masak nasi pulut wajik bila saya nak suroh isteri masak nasi pulut wajik when I want ask wife cook rice pulut wajik When I want (it), (I) ask (my) wife (to) cook pulut wajik rice. 
In the sentential construction of 6 , the constituent assuming the role of Agent is the noun gendei. In relation to the verb masak which means 'to cook', gendei is acting on her own volition in the act of

6) e ed masak gulei goreng kari saya masak gulai goreng kari I cook gravy fried curry I cook gravy fried (fried food) and curry.
From the sentential construction above, it can be identified that $e$ ed is the noun constituent linked to the verb masak. This is due to the fact that $e$ ed is the initiator of the action. Additionally, the noun cooking. In another example, the verb masak is linked to the agent theta role through a noun constituent. The sentence below shows another example.

\section{c. Agent Theta Role in Relation to the Verb Hagak}

7) bila eed hagak suroh gendei masak nasi pulut wajik bila saya nak suroh isteri masak nasi pulut wajik when I want ask wife cook rice pulut wajik When I want (it), (I) ask (my) wife (to) cook pulut wajik rice.

8) eed hagak cok laut ari ujan telok ketam Saya nak pergi laut hari hujan cari ketam I want go sea day rain find crab I want (to) go (to the) sea, (the) rainy day (was) rain(ing) (to) look for crab.

9) eed hagak beli barang kemaih saya nak beli barang kemas I want buy thing jewellery I want to buy jewellery.

In the sentential construction of 7 , it features the same sentence as in 5 . In this sentence, two verbs are featured. Previously, the verb discussed in relation to the Agent is masak. However, in this sentential construction, the verb hagak is taken to examine the Agent theta role. In this particular sentence, the noun $e$ ed is the Agent who is acting on his own volition in the quest for pulut wajik rice. Next, in the sentential construction of 8 , the noun $e$ ed assumes the role of an Agent. In particular, e ed now has the volition of desiring to go to the sea. Therefore, this noun constituent can initiate the action of hagak. In the last sentential construction of 9 , e ed is also the Agent by having the volition of hagak. The noun $e$ ed expressed his want of buying jewellery and it is a possibility for $e$ ed to carry out the aforementioned act.

\section{d. Agent Theta Role in Relation to the Verb Suroh}

Another predicate involved in the sentential construction in $\mathrm{b}$ and $\mathrm{c}$ is the verbs uroh. With reference to the same sentence featured in number $b$ and $c$, the 
verb suroh which means 'ask' is related to the noun constituent of $e e d$. This adds to the number of predicates related to e $e d$. As demonstrated earlier, the noun e ed shows its capability to have the action of wanting the pulut wajik rice. In the next verb suroh, $e e d$ is also an initiator of the action of asking for the pulut wajik rice.

\section{e. Agent Theta Role in Relation to the Verb Beli}

In this section, the verb discussed in relation to an Agent theta role is beli. As seen in sentence 10 below, the argument which assumes the role of Agent is the noun $e$ ed. It is shown that $e$ ed is capable of volition of the action beli. Therefore, $e$ $e d$ can also be understood as the initiator of the action of buying groceries in a particular supermarket or a grocery shop. In the last sentential construction of 11, e ed is also the Agent by having the volition of hagak. The noun $e$ ed expressed his wish of buying jewellery and it is a possibility for $e$ ed to commit the aforementioned act.

10) eed beli barang hak pasaraya ataupun kedai runcit saya beli barang di pasaraya ataupun kedai runcit I buy grocery at supermarket or shop grocery I buy grocery at (the) supermarket or grocery shop.

11) eed hagak beli barang kemaih saya nak beli barang kemas I want buy thing jewellery I want to buy jewellery.

\section{f. Agent Theta Role in Relation to the Verb Cok}

Another verb linked to the Theta Role of Agent is the verb cok. In the example below, the Agent is identified by the noun $e e d$. In this case $e d$ is understood as the participant which is involved in the action of going to Banting town. Here, the noun $e$ ed is also the initiator of the action cok.

12) selalu eed cok pekan Banting Selalu saya pergi pekan Banting always I go town Banting I always go (to) Banting town.

The sentential construction shows $e$ ed as the initiator or participant who by his own volition frequents the town constantly. Below are other different sentential constructions involving the Theta Role of Agent in other situations utilising the verb cok.

13) $n g k i$ cok leh

dia pergi lah

he go

He goes. 
14) hik cok leh gol bara kei

awak pergi lah ambil barang itu

you go take thing that

You go (and) take that thing.

15) eed hagak cok laut ari ujan telok ketam

saya nak pergi laut hari hujan cari ketam

I want go sea day rain find crab

I want (to) go (to the) sea, (the) day (was) rain(ing) (to) find crab.

All of the sentences above reveal different constituents or participants representing the role of Agent. From the data above, sentences 13,14 and 15 have the noun constituents of $n g k i$ 'he', hik 'you' and e ed 'I', respectively. In sentence 13, ngki acts as an Agent as the participant is able to commit to the act of going. Furthermore, ngkiis is the initiator of this action. In a similar setting, the noun constituent of hik conveys the role of Agent as well. Hik shows the ability or has the volition to commit the act of going in order to retrieve things. The last sentential construction demonstrates the noun constituent $e$ ed as the Agent. This is proven by the constituent's ability of committing the act of cok. Furthermore, $e$ $e d$ is able to initiate this action by his own willpower.

\section{g. Agent Theta Role in Relation to the Verb Caik}

In the sentential construction using the verb caik, it is found that the accompanying Agent is e ed. The participant $e$ ed is seen to commit the act of caik or find. Furthermore, the Agent is the initiator of this action. This can be gathered from the following sentence below.

16) kadang-kadang eed caik udang caik ka bawal ka ngaik Kadang-kadang saya cari udang cari ikan bawal ikan ngaik Sometimes I find prawn find fish pomfret fish ngaik Sometimes I find prawn, pomfret fish, or ngaik fish.

\section{h. Agent Theta Role in Relation to the} Verb Naik

The verb naik is used with the Theta Role of Agent. In the example below, the noun constituent of $e$ ed is the initiator of the action naik. Besides that, the participant $e$ ed is also capable of the action of riding a boat.

17) e ed naik pahuk

saya naik perahu

I ride boat

I ride (a) boat.

\section{i. Agent Theta Role in Relation to the Verb Nyut}

18) eed nyut deieh doh yal

saya balik petang air pasang

I return evening water high

I return (in the) evening (when the) tide is high. 
19) hinong ngki nyut

sekarang dia balik

now she return

Now, she (has) return(ed).

As shown above, sentences 18 and 19 show two different constituents taking the role of Agent. The noun constituents are $e e d$ and $n g k i$ respectively. In 18, e $e d$ plays the role of an Agent in the action of nyut or returning, and in 19, the Agent theta role is taken by the noun constituent $n g k i$.

\section{j. Agent Theta Role in Relation to} the Verb Gol

An Agent theta role is also apparent in a few sentential constructions which include the verb gol. This verb carries the meaning of take.

20) eed hagak ka bawal gol jaring bawal saya nak ikan bawal ambil jaring bawal I want fish pomfret take net pomfret I want (a) pomfret fish, (so) I take the pomfret net.

21) hik gol barang nakei

awak ambil barang itu

you take thing that

You take that thing.

22) nake gol moyang

itu ambil moyang

that take ancestor

That (person) takes (the)

ancestor. (Any person from whom one is descended) In the featured sentential constructions above, each sentence has a different constituent representing the Agent theta role. In sentence 20, the noun constituent $e$ ed is the Agent for the action of gol. In the sentence 21, the noun constituent hik is represented as the Agent. In contrast, sentence 22 shows a problem in the representation of Agent. In this particular sentence, there is no apparent argument which takes on the predicate of gol. This is because the only

particular constituent that is present is an expletive nake. Thus, even though it may be understood from the context that the speaker was referring to a person, nake cannot be an Agent because an expletive cannot assume a Theta Role as it is not an argument and does not refer to any entity.

\section{Theme}

All sentences which possess the Theta Role or Thematic Relation of Theme are featured and discussed in this particular section.

\section{a. Theme Theta Role in Relation to the Verb Suka}
23) e ed
suka
nasi pulu
wajik
saya suka nasi pulut wajik
I like rice pulut wajik
I like pulut wajik rice. 
24) budak budak eed suka kuih wajik

budak budak saya suka kuih wajik

child child I like dessert wajik

My children like wajik dessert.

25) eed suka lagu Jobok

saya suka lagu Melayu

I like song Malay

I like Malay songs.

From the sentential constructions above, there are three noun constituents which are identified as Themes of the sentences. The noun constituent of 23 ' $\mathrm{e} \mathrm{ed}$ ' is the Agent for the sentential construction of the sentence $e$ ed beh sendiri kuih wajik (Mah Meri). In the next sentence, the noun constituent budak-budak e ed assumes the theta role of Theme because it is the topic of sentence. Consequently, in sentence 25, the noun constituent $e$ ed is acknowledged as the Theme of that particular construction. Therefore, all of these aforesaid arguments are linked to the verb suka as the Theme for each sentential construction.

\section{b. Theme Theta Role in Relation to the Verb Kabe/Beh}

The other verb which is closely related to the Theta Role of Theme is the verb beh. The verb beh is linked to some noun constituents assuming the Theta Role of Theme such as kuih wajik, wajik and kejak.
26) eed beh sendiri kuih wajik
Saya buat sendiri kuih wajik
I make myself dessert wajik
I make wajik dessert myself.

27) kedo eed yang beh wajik untuk eed

isteri saya yang buat wajik untuk saya

wife I that make wajik for I

My wife makes wajik for me.

28) ngki macam-macam kejak kabe

dia macam-macam kerja buat

he various work do

He (has) done various types of work.

In the sentential construction of 26 , the noun constituent assuming the Theme theta role is kuih wajik. In sentence 27, wajik undertakes the role of Theme whereas in sentence 28, kejak is the identified Theme. For each Theme it is understood from the sentences that each identified noun constituent is undergoing an action. As an example, in sentence 26, kuih wajik is undergoing the action of being made by the other noun constituent $e$ ed. Sentences 27 and 28 also show wajikand kejak as entities that are experienced or perceived. Thus, the examples above show that the Themes linked to the verb kabe, also known as beh, are kuih wajik, wajik and kejak. 


\section{c. Theme Theta Role in Relation to the Verb Beli}

The next verb that is explored to find the Theme theta role is the verb beli which denotes the meaning of buy. The following examples illustrate the Theme theta roles.

29) eed beli barang hak pasaraya ataupun kedai runcit

saya beli barang di pasaraya ataupun kedai runcit I buy grocery at supermarket or shop grocery I buy grocery at (the) supermarket or grocery shop.

30) eed hagak beli barang kemaih

saya nak beli barang kemas I want buy thing jewellery I want to buy jewellery.

In the sentential construction above, it is found that the Theme for sentence 29 is the noun constituent barang while in latter sentence of 30 barang kemaih has the
Theta Role of Theme. In examples, the nouns barang and barang kemasare undergo the action of sentences.

\section{d. Theme Theta Role in Relation to the Verb Hagak}

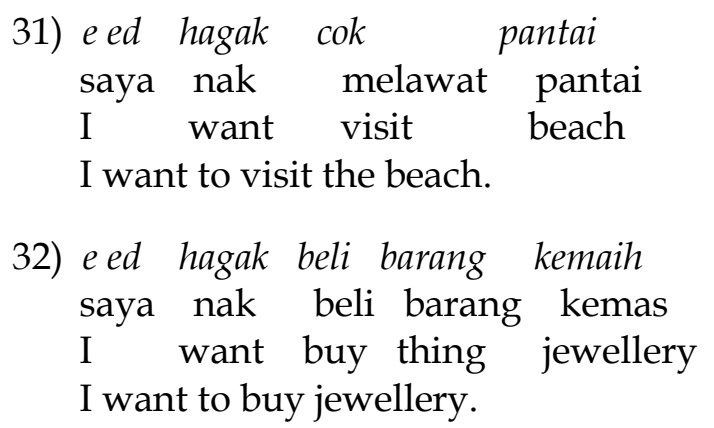

In the above sentences, the noun constituents undertaking the position of Theme are pantai and barang kemaih respectively. In the sentential construction of 31, the noun constituent of pantai is the entity which is experienced or perceived by $e$ ed. In comparison, the sentential construction of 32 exemplifies barang kemas as the entity which is the object of perception of the noun constituent $e e d$. Thus, it is evident that both pantai and barang kemas are Themes as they undergo a psychological aspect of change through the noun constituents of $e e d$.

\section{e. Theme Theta Role in Relation to the Verb Caik}

The verb caik is pertinent in discussing the Theta Role of Theme. The verb caik, meaning find shows many examples of Theme in a sentential construction. The following sentence below elucidates the idea.

33) kadang-kadang e ed caik udang caik ka bawal ka ngaik Kadang-kadang saya cari udang cari ikan bawal ikan ngaik Sometimes I find prawn find fish pomfret fish ngaik Sometimes I find prawn, pomfret fish (and) ngaik fish. 
From the sentential construction above, the identified Themes are the noun constituents; udang, ka bawal and ka ngaik. From the above sentence, it is understood that these noun constituents are experienced by the finder. For example, the experience of caik udang or finding prawns is an experience which $e$ ed undertakes. Correspondingly, the other noun constituents such as ka bawal and ka ngaik are also the entities which are perceived by $e$ ed. Therefore, the Themes present in the above sentence are udang, ka bawal and ka ngaik.

\section{f. Theme Theta Role in Relation to the Verb Keghat-Keghat}

34) air mawar mawar keghat keghat
air mawar mawar dikerat kerat
water rose rose slice slice

(For the) rose water, the rose (petals) are sliced.

In the sentential construction above, the verb keghat-keghat is affecting the noun constituent mawar. From the sentence, it is understood that mawar undergoes an action. In this case, the noun mawar undertakes the action of being sliced. Hence, the Theme of this sentence is mawar or rose as it is affected by the action.

\section{Experiencer}

In this section, the Theta Role or Thematic Relation of Experiencer is explored. All sentences which bear the Theta Role of Experiencer are featured in this section.

\section{a. Experiencer Theta Role in Relation to the Verb Suka}

The Theta Role of Experiencer can be seen in the sentential construction related to the verb suka. The verb suka is paired with the Theta Role of Experiencer as it shows feelings.

35) eed suka nasi pulut wajik saya suka nasi pulut wajik I like rice pulut wajik I like pulut wajik rice.

36) budak budak eed suka kuih wajik budak budak saya suka kuih wajik child child I like dessert wajik My children like wajik dessert.

37) e ed suka lagu Jobok saya suka lagu Melayu I like song Malay I like Malay songs.

Closely related to the predicate suka is the Experiencer of each particular sentential construction. In relation to the particular sentences above, 35 demonstrates the noun constituent $e$ ed as the Experiencer. Next, the Experiencer for the sentence of 36 is the noun constituent of budak-budak e ed. Lastly, the identified Experiencer for 37 is $e e d$. From the sentences above, it is clear that 
the Experiencers are the ones who experience or perceive the events. In this case, the sentential constructions indicate that $e$ ed and budak-budak e ed are the ones that perceive the idea of liking either pulut wajik rice, wajik dessert or Malay songs.

\section{b. Experiencer Theta Role in Relation to the Verb Rasa}
38) eed rasa nasi pulut wajik lawan kopi sedap
saya rasa nasi pulut wajik dengan kopi sedap
I feel rice pulut wajik with coffee tasty
I feel (that) pulut wajik rice with coffee (is) tasty.

In the above sentential construction, the Theta Role of Experiencer is discussed with the verb rasa. The verb rasa (feel) is perceived by the Experiencer $e$ ed. In this example, $e$ ed is the perceiver of the action rasa. Thus, it can be said that the argument $e e d$ is the experiencer.

\section{Benefactor}

The Theta Role of Benefactor is found in a sentential construction. The relevant sentential construction is discussed below.

\section{a. Benefactor Theta Role in Relation to the Verb Beh \\ In relation to the Theta Role of \\ Benefactor, the verb beh is examined in a sentential construction. This can be identified from the example below.}

39) kedo eed yang beh wajik untuk eed isteri saya yang buat wajik untuk saya wife I that make wajik for I My wife makes wajik for me.

From the sentential construction, it is determined that the Theta Role of Benefactor is the noun constituent $e$ ed. The noun constituent $e$ ed is the Benefactor of the wajik dessert which is made by his wife for him. Thus the verb 'beh' is the predicate of the sentence which undergoes the benefactor role.

\section{Instrument}

The Theta Role of Instrument is also found in the sentential constructions.

40) eed naik pahuk

saya naik perahu ke pantai

I ride boat to beach

I ride a boat to the beach.
The discussion for the Theta Role of Instrument is presented below.

\section{a. Instrument Theta Role in Relation to the Verb Naik}

The Theta Role of Instrument is found in the sentential construction involving the verb naik. Following two examples link the verb naik with the Theta Role of Instrument. 
41) Daud ke kejak naik moto

Daud ke kerja naik motor

Daud to work ride motorcycle

Daud rides (the) motorcycle to work.

There is an Instrument linked to each sentential construction in 40 and 41 . For the first sentence of 40 , the noun constituent is pahuk. Pahuk (boat) is considered the Instrument as it is the entity with which action occurs. It can also be said that it is a theme of the sentence as it undergoes the action. However, here in this sentence it is used as an instrument to go to the beach. In this example, the action of naik occurs with the Instrument of pahuk. In another similar setting, the noun constituent assuming the role of Instrument in 41 is moto. From the sentence above, the action of naik only occurs with the entity of moto. Therefore, it is deduced that two examples of Instrument found are pahuk and moto.

\section{Locative}

The Theta Role of Locative is one of the categories of Theta Roles discussed in this study. The sentential constructions which are linked to this category involve the verb kejak, beli, sekolah and geteik. The following examples show the Locatives in their own respective settings.

\section{a. Locative Theta Role in Relation to the Verb Kejak}

The Theta Role of Locative is found to be linked with the verb kejak. In the sentential construction below, the identified locatives are the noun constituents Banting and Tembuk.

42) Daud kejak mesin rumput hak Banting sampai ke Tembuk.

Daud kerja mesin rumput di Banting sampai ke Tembuk.

Daud work machine grass at Banting until to Tembuk.

Daud works (with) grass-cutting machine from at Banting to Tembuk.

The above example shows that the action had taken place from Banting to Tembuk. Thus, the Locative in the above sentence is Tembuk.

\section{b. Locative Theta Role in Relation to the Verb Beli}

In the next sentential construction, it is determined that the noun constituents assuming roles of Locatives are pasaraya and kedai runcit. The following sentence below shows the Locatives in their environments.

43) eed beli barang hak pasaraya ataupun kedai runcit saya beli barang di pasaraya ataupun kedai runcit I buy grocery at supermarket or shop grocery I buy grocery at (the) supermarket or grocery shop.

From the example above, it is evident that the arguments pasaraya and kedai runcit are the Locatives in which e ed carried out the action of beli. Thus, the places involved in this sentence are the supermarket and the grocery shop. 


\section{c. Locative Theta Role in Relation to the Verb Sekolah}

In the following sentence, the argument undertaking the role of a Locative is Sekolah Teluk Datuk.

44) ngki sekolah hak Sekolah Teluk Datuk
dia sekolah di Sekolah Teluk Datuk
she school at School Teluk Datuk
She studies at Teluk Datuk School.

The noun constituent which assumes the Locative theta role in the above sentence is clearly stated. This is because the action of sekolah takes place in the aforementioned Location. Hence, Sekolah Teluk Datuk is the responsible Theta Role of Locative in the above sentence.

45) ngki geteik asrama ngot
dia tinggal asrama tidak
he live hostel not
He does not live (at the) hostel.
46) Hanom hak geteik asrama
Hanom di tinggal asrama
Hanom at live hostel
Hanom lives at (the) hostel.

In both sentential constructions of 45 and 46 , the argument asrama is identified as the Locative for each example. Both highlight the aspect that asrama is the place of the action. Thus, it can be said that the argument for each sentence assumes the role of a Locative.

\section{Goal}

In this section, the last category of Theta Roles, i.e. Goal is explicated. The Goal is defined as the entity towards which a motion takes place. This may involve an abstract motion. The findings show that verbs which are linked to Goal are beh, cokand gol. However, the last example is highlighted to show the preposition of $k e$

\section{d. Locative Theta Role in Relation to the Verb Geteik}

In the next Theta Role of Locative, the verb geteik is discussed in the following sentences. acting as a replacement for a verb. The following examples expound the related Goals with the verbs in their respective settings.

\section{a. Goal Theta Role in Relation to the Verb Beh}

The Goal theta role is seen in the following sentences. The Theta Role of Goal is found to be the noun constituent $e e d$. The argument $e$ ed shows the goal towards which the action of beh wajik is intended. The argument e $e d$ is classified as a non-abstract goal as $e e d$ is a person. To illustrate, the sentence involving the Theta Role of Goal is given below. 
47) kedo eed yang beh wajik untuk eed isteri saya yang buat wajik untuk saya wife I that make wajik for I My wife makes wajik for me.

From the sentence above, it is argued that goal theta role is located at the end of the sentence. The noun constituent $e$ $e d$ is the goal having the Goal theta role. It is used with the other noun constituents such as kedo e ed and also wajik.

\section{b. Goal Theta Role in Relation to the Verb Cok}

Another verb which is related to the Theta Role of Goal is cok. Cockatrices the meaning of go. In this section, the related sentential constructions which feature the verb cok with the Theta Role of Goal are shown below.

48) selalu eed cok pekan Banting

selalu saya pergi pekan Banting always I go town Banting I always go (to) Banting town.

49) hikcok leh gol bara kei awak pergi lah ambil barang itu you go take thing that You go (and) take that thing.

50) eed hagak cok laut ari ujan telok ketam sayanak pergi laut hari hujan cari ketam I want go sea day rain find crab I want (to) go (to the) sea, on (the) rainy day (to) look for crab.

The Theta Role of Goal can be seen in all three sentences above. In 48 , the Goal is pekan Banting. It is the goal of the argument $e$ ed. In 49 , the Goal is identified as bara (thing). The argument bara is paired with another argument hik. In 50, the Goal is laut. Hence, the noun constituents which assume the role of Goal are pekan Banting, bara and laut respectively.

51) nake gol moyang itu ambil moyang that take ancestor That (person) takes the ancestor.

In the sentence above, the Goal is assumed by the noun constituent

\section{c. Goal Theta Role in Relation to the Verb Gol}

Another verb which can be seen to include the Theta Role of Goal is gol. The verb gol, or also known as kagol, denotes the meaning of take. In relation to this verb, the sentential construction below provides evidence for this Theta Role. 
ENGLISH REVIEW: Journal of English Education Vol. 5, Issue 1, December 2016
ISSN 2301-7554

https://journal.uniku.ac.id/index.php/ERJEE
However, the determiner nake serves as a marker of a missing noun constituent. In this situation, the seemingly missing noun constituent is pursuing the entity of moyang.

\section{d. Goal Theta Role in Relation to the Preposition Ke Acting as a Verb}

52) kadang kadang ke laut

$$
\begin{aligned}
& \text { kadang kadang ke laut } \\
& \text { sometimes to sea } \\
& \text { Sometimes (I go) to the sea. }
\end{aligned}
$$

From the example above, it is identified that the Theta Role of Goal is assumed by the noun constituent laut.

\section{Discussion of Sentences without Any Theta Roles}

This section discusses the sentences without any Theta Roles. These are the sentences which do not fit under any category under Radford's definition (1997) of Theta Roles. Radford (1997) clarified that in order for Theta Roles to be analysed, the predicate and the argument must be present at all times. However, it is found that some sentential constructions in Mah Meri can still be logical or grammatically correct without

$$
\begin{aligned}
& \text { 53) nelayan pon dak le } \\
& \text { nelayan pun tidak lah } \\
& \text { fisher man also not } \\
& \text { (I'm) also not a fisherman. }
\end{aligned}
$$

In the sentence above, a Theta Role is unavailable as it does not fulfil the rule of having a predicate. Thus, even though a noun constituent is present, the sentential construction cannot be analysed due to the aforementioned reason.
In the following sentence, there is no verb constituent involved. However, it is found that the preposition $k e$ (to) acts as a verb predicate. In this case, it is analysed that sentences can function with the preposition $k e$ as a replacement for the verb cok. This finding is explicated through the sentential construction below.

having a predicate. Hence, this section discusses in detail the Theta Roles involved such as Agent, Experiencer, Theme, Goal, Recipient, Source, Location, Instrument and Benefactive.

\section{a. Discussion of Sentential Construction 1}

In the sentential construction below, it is analysed that no Theta Role is present. The reason for the absence of any Theta Role is due to the lack of predicate or verb in the particular sentential construction. The following sentence explicates the lack of verb in the sentence uttered by the speaker.

\section{b. Discussion of Sentential Construction 2}

The next sentential construction contains a noun constituent. However, this type of sentential construction could not have a Theta Role as it also lacks a predicate. The following example shows this. 
54) nama kenon suluk Ajin

nama anak sulung Ajin

name child first Ajin

(The) first child's name (is) Ajin.

The example above indicates zero predicate. However, it does have a noun constituent 'Ajin'. Since the sentence has zero predicate; thus, its noun constituent cannot be assigned any Theta Roles.

55) bali pon ada

bali pun ada

pomelo also available

There is also pomelo.

In the above sentential construction, the noun constituent which is present is bali. Bali is translated as pomelo (a type of fruit) cannot take on any Theta Role as there is no predicate available. Hence, it is concluded that from the sentence above that no category of Theta Role can be assigned to the noun constituent bali.

$$
\begin{aligned}
& \text { 56) nama ngki Daman } \\
& \text { nama dia Daman } \\
& \text { name he Daman } \\
& \text { His name (is) Daman. } \\
& \text { 57) nama ngki Lina } \\
& \text { nama dia Lina } \\
& \text { name she Lina } \\
& \text { Her name (is) Lina. } \\
& \text { 58) nama ngki Hanum } \\
& \text { nama dia Hanum } \\
& \text { name she Hanum } \\
& \text { Her name (is) Hanum. }
\end{aligned}
$$

As seen above, there is no indication of any predicate in the sentential construction for all the sentences in d. It is found that only a noun constituent is

\section{c. Discussion of Sentential Construction 3}

The discussion continues with another type of sentential construction. The sentence below shows the lack of a predicate as well.

\section{d. Discussion of Sentential \\ Construction 4}

Further discussion of sentential constructions without any Theta Roles is discussed in this section. Like the previous sentential constructions, no verb or predicate can be determined from any of the sentential constructions. The following examples explicate the findings.

present in each sentence. As seen in 56, the noun constituent Daman cannot be assigned any Theta Roles as it is not linked with any predicates. Hence, 
Daman cannot be constituted for an argument of any Theta Role. In a similar setting as 56 , the sentential construction of 57 is devoid of any predicate. In 57, the identified noun constituent for this sentential construction is Lina. Lastly, the sentence 58 also indicates the absence of any predicates. It features the same syntactic placement as demonstrated in 56 and 57. In addition, it also includes a single noun constituent, Hanum.

Nonetheless, the conclusion is the same for all the sentential constructions in $\mathrm{d}$. All of these sentential constructions indicate the deficiency of verbs. Hence, none of the aforementioned noun constituents of Daman, Lina and Hanum can undertake any Theta Role in their respective sentences.

\section{e. Discussion of Sentential Construction 5}

The sentential construction 5 echoes the idea of an absent predicate. This finding is also prevalent in the previous discussion in relation to the sentential constructions without a verb. However, it is interesting to note that instead of one noun constituent present, the sentence featured below has two different noun constituents. To illustrate, the sentence construction is shown below.
59) $T o k$
Batin darjah enom huk
Tok
Batin darjah enam
sahaja
Tok
Batin standard six only
Tok Batin studies till standard six only.

The sentential construction above discusses the two separate entities of noun constituents. Nonetheless, it is determined that a verb or a predicate is unrepresented in the sentential construction above.

\section{f. Discussion of Sentential Construction 6}

The sixth type of sentential construction found in the Mah Meri language that is not represented by any Theta Role is shown below.

60) adat hum penting adat mandi penting Tradition bathe important (The) bathing tradition (is) important.

As seen in the sentential construction above, there is no particular predicate in the sentence. However, it is seen that adat hum is a noun constituent. However, due to the lack of predicates, this noun constituent cannot assume any Theta Role due to the lack of predicates. Hence, this sentential construction cannot be analysed for the Theta Role.

\section{CONCLUSION}

From this data, all Theta Roles are found to be presented except for the Theta Role of Recipient. However, this is not due to the lack of the Theta Role of Recipient in Mah Meri. Rather, it is due to the limitation of the scope in this study as the data analyzed was based on the limited interview. The Agent theta role is a prominent one in the Mah Meri language; it has the highest level of occurrence in the data. The researcher 
observed some repeated noun constituents as Agents. Some of these noun constituents are $e^{\prime} e d(\mathrm{I}), n g k i$ (he/she) and hik (you). However, other noun constituents are also found such as kedo e'ed (my wife). Besides kedo e'ed, the researcher detected proper names to have also taken on the roles of the Agent. These proper nouns are such as Hanom, Bakhtiar, and Daud to name a few.

The second type of Theta Role found in the study is Theme; having second highest occurrence in the data. It is seen that Theme is often paired along with the Agent theta role. However, it is interesting to note that the Theta Role of Theme has the most variety of types. Unlike the Theta Role of Agent which are often the same repeated noun constituents, the Theta Role of Theme is found to be more dynamic. Some examples of the Theme are laut (sea), barang kemaih (jewellery), udang (prawn), ka bawal (pomfret fish) and mawar(rose) to name a few.

The third type of Theta Role is the Theta Role of Experiencer. The researcher found that the Theta Role of Experiencer is very similar to that of the Theta Role of Agent; assuming that the agent is in the specifier of a light verb, these observations suggest that the experiencer is in the specifier of the thematic verb, like theme arguments (Radford, 1997). The same type of example is found to assume the role of an Experiencer. These examples include the use of the noun constituent $e^{\prime} e d(\mathrm{I})$. The other noun constituent which undertakes the Experiencer theta role is budak-budak e'ed (my children). However, it is found that Experiencer theta role occurs less in the data as compared to Agent.

The fourth type of Theta Role denotes the Theta Role of Benefactor. The Theta Role of Benefactor is found to be present in one of the sentential constructions in Mah Meri. The noun constituent which carries the role of Benefactor is $e^{\prime} e d(\mathrm{I})$. In comparison, the fifth type of Theta Role of Instrument shows a different set of noun constituents assuming the role. The examples of Instrument are the noun constituents of pahuk (boat) and moto (motorcycle). Finally, the Theta Role of Locative shows variation as well. Some of the noun constituents found to carry this role are anting, Tembuk, and pasaraya (supermarket). Thus, it can be concluded that Mah Meri has all theta roles except Recipient. However, the cause is not due to lack of the theta role of recipient in the Mah Meri, but it is perhaps due to the limited data.

\section{REFERENCES}

Carnie, A. (2007). Syntax: A Generative introduction (2nd ed.). UK: Blackwell Publishing.

Hajek, J. (1996). Unraveling Lowland Semang. Oceanic Linguistics, 35(1), pp. 138-141.

Kruspe, N. (2004). A grammar of Semelai. Cambridge: Cambridge University Press.

Kruspe, N., \& Hajek, J. (2009). Mah Meri. Journal of the International Phonetic Association, 39(02), pp. 241248.

Luraghi, S., \& Parodi, C. (2008). Key terms in Syntax and Syntactic theory. Continuum.

Omar, A. H. (2006). Kamus Mah Meri-MelayuInggeris. Kuala Lumpur: University of Malaya Press.

Radford, A. (1997). Syntax: A Minimalist introduction. Cambridge: Cambridge University Press.

Radford, A. (2009). An Introduction to English sentence structure. Cambridge: Cambridge University Press.

Sebeok, T. A. (1942). An Examination of the Austroasiatic Language Family. Language, pp. 206-217. 
ENGLISH REVIEW: Journal of English Education Vol. 5, Issue 1, December 2016

Sebeok, T. A. (1943). The languages of Southeastern Asia. The Far Eastern Quarterly, 2(4), pp. 349-356.

Stevens, M., Kruspe, N., \& Hajek, J. (2006). Register in Mah Meri: A preliminary Phonetic

Analysis. In R. Hoffmann \& H. Mixdorff (Eds.), Proceedings of Speech Prosody (pp. 269-272). Dresden, Germany: ISCA. Retrieved from: http://www.iscaspeech.org/archive/sp 2006

Veesar, Z. A., Kadhim, K. A., \& Sriniwass, S. (2015a). Establishing the Thematic Structure and Investigating the most Prominent Theta Roles Used in Sindhi Language. International
ISSN 2301-7554

https://journal.uniku.ac.id/index.php/ERJEE

Journal of Applied Linguistics and English Literature, 4(4), pp. 216-230.

Veesar, Z. A., Sriniwass, S., \& Kadhim, K. A. (2015b). A Comparison of Theme Theta Roles in English and Sindhi. Language \& Communication, 2(1), pp. 77-89.

Veesar, Z. A., Kadhim, K. A., Shah, S. A., \& Khuhro, R. A. (2016). Argument Structure of Sindhi Verbs: An Analysis of Thematic Relations. Language in India, 16(2).

Veesar, Z. A., Kadhim, K. A., \& Bagudu, R. S. (2016). The Most Prominent Theta Roles in the Sindhi Language: The Hierarchy. International Journal of Foreign Language Teaching and Research, 3(12), pp. 11-24. 


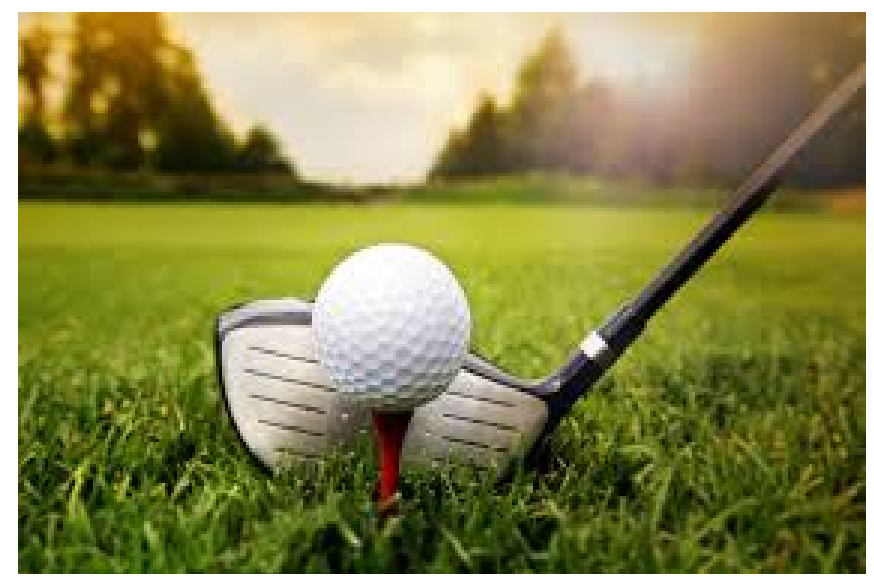

\section{Golf Ball}

Two Golfers were approaching the first tee. The first guy goes into his golf bag to get a ball and says to his friend - "Hey, why don't you try this ball." He draws a green golf ball out of his bag. "Use this one - You can't lose it!" His friend replies, "What do you mean you can't lose it?!!" The first man replies, "I'm serious, you can't lose it. If you hit it into the woods, it makes a beeping sound, if you hit it into the water it produces bubbles, and if you hit it on the fairway, smoke comes up in order for you to find it." Obviously, his friend doesn't believe him, but he shows him all the possibilities until he is convinced. The friend says, "Wow! That's incredible! Where did you get that ball?" The man replies, "I found it."

(Source: http:/ / www.study-express.ru/humour/funny-stories.shtml, picture: www.google.co.id) 